\title{
Research in the market-place
}

\author{
Dorothy Nelkin
}

The Interferon Crusade: Public Policy and Biomedical Dreams.

By Sandra Panem.

The Brookings Institution, I775 Massachusetts Avenue NW, Washington DC/ Costello, 43 The High Street, Tunbridge Wells, Kent: 1984. Pp. 109. Hbk \$22.95, £31; pbk \$8.95, f12.10.

\begin{abstract}
"A MAGIC bullet", "a priceless miracle drug", "a cure for cancer", "a wonder therapy" - it was in these terms that the public was exposed to research on interferon. Interferon has been the most visible and dramatic product of the rapidly expanding biotechnology industry. The story of its development and the hyperbole that surrounded it reflect the mix of scientific, political and economic events that has generally shaped the biotechnology revolution. It is a story of promises and problems, of complex arrangements between government, industry and academia, and of the policy dilemmas of a fast-moving and potentially profitable field of research.
\end{abstract}

Sandra Panem's book, The Interferon Crusade, begins with the discovery in the 1950 s that the body produces a natural therapeutic agent, "an interfering proton" to inhibit infections. Panem traces the development of interferon, documenting the discovery of its anti-tumour activity in 1967 , the publicity about its potential as a cancer cure in the mid-1970s, and finally the successful cloning of a human interferon gene in late 1979. She writes also about the role of advocacy scientists, those key individuals who publicize research, capitalizing on the public fear of cancer in order to raise funds.

As Panem observes, the explosion of interest in interferon resulted mainly from its promise as a cure for cancer. The ability to synthesize the drug through genetic engineering techniques, and therefore to produce it inexpensively, aroused commercial attention so that interferon became the primary lure for trapping venture capital for biotechnology firms. The case of interferon reveals the complex institutional relationships involved in new technologies. It engaged scientists and politicians in marshalling resources to develop the technology; it attracted the interest of the press; and eventually it succeeded in mobilizing public curiosity and venture capital. The academic community, the government and the private sector developed close relationships.

The book points to the controversial policy issues raised by these relationships - the effect of extra-scientific factors such as media attention in setting research priorities, for example, and the influence of commercial interests on academic research and on the behaviour of the scientific community. It also deals with the conflicts over open disclosure of research findings, the manpower problems of a rapidly expanding scientific and technical field, the ethical and legal consequences of the changing relationship between science

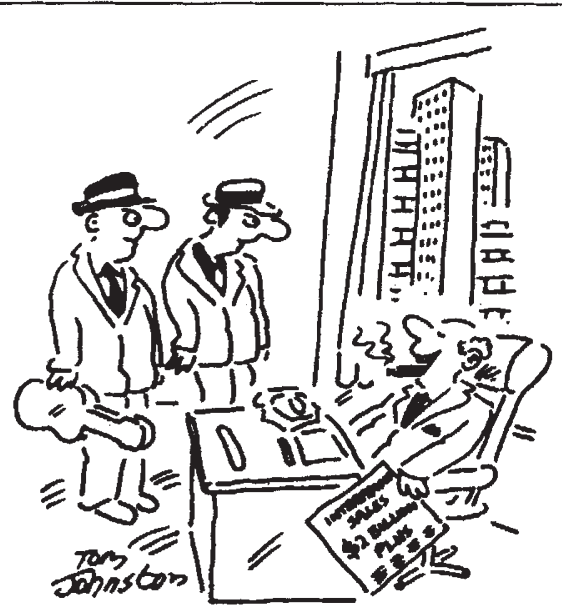

"Forget the heroin business, Bugsy! I've someining more profliable lined up!"

ACCORDING to a report prepared by the US brokerage and investment firm Bache Halsey Stuart Shields, interferon sales could have a world wide market of $\$ 2$ billion a year within three to five years. The report, summarised in European Chemical

Interferon fever - cartoon and news report from Nature May 1980.

and industry, and the complexity of funding patterns that arise from the involvement of both the public and the private sectors.

Panem is at her best when she discusses the history of the development of interferon, and its scientific importance in molecular biology and immunology despite its failure in the short term as a therapeutic agent. She writes skilfully of the dynamics of the biotechnology industry and the role of media, both in shaping research priorities and attracting industrial interest. The people, the firms, are real, and their activities are richly portrayed. However, she presents the key policy issues as little more than a list. There is much more to be explored in the problems of secrecy so often observed as a consequence of the new associations between science and industry engendered by the growth of biotechnology. How great a problem is secrecy in science? What kind of contracts are being developed, and what is their effect? What is the actual influence of nondisclosure on scientific productivity?

One suspects the changing relationship between science and scientists and their sponsors is also changing the prestige system in science. Rewards are increasingly coming from consulting contracts, from participation on corporate boards. What does all this mean? At some universities entire biology departments have been redirected to research in genetic engineering and biotechnology-related research. What does this imply for the training of students, and more generally, for the wider range of biological research? There are also many questions to be asked about the selling - the overselling - of science, and Panem makes a fascinating observation about the role of "hype" on funding patterns. Between 1978 and 1981 the increase in government spending on interferon research greatly outpaced the overall rate of growth in biomedical research in general. Yet the peer review ratings were much lower, suggesting how politicians more than peers can shape scientific priorities. What are the implications of this pattern of funding "hot" research subjects before good proposals are developed? When commercial interests influence research funding, what does this do to the ideal of science as an autonomous, neutral activity? While the focus on fashionable areas of research has implications for science itself, there are perhaps more serious implications for the rest of us.

The overselling of interferon also bears on the credibility of science as a whole. In many cases, scientists contributed to media publicity, believing that it was an effective way to attract support. But this also created inflated public expectation and then disillusion as delivery of therapeutic benefits was delayed. As one journalist cynically observed about interferon, "At only a hundred trillion dollars a gram, this miracle drug has a future".

Panem competently outlines the policy dilemmas intrinsic to this revolutionary area of research, but she offers no point of view. Her descriptions of the "interferon crusade" are balanced, but bland: she takes no position on the many controversial issues that she lists. Her view, as stated in the introduction, is that "understanding the interferon experience may prove useful in predicting future problems of biomedical research [and] other scientific areas as they experience technical revolutions". She has laid the groundwork for such an understanding, but it remains for others to examine with a more critical and analytical eye the dilemmas that are outlined in her book.

Dorothy Nelkin is a Professor in the Program on Science, Technology and Society, and in the Department of Sociology at Cornell University. 